\title{
Life cycle of the apple snail Pomacea canaliculata (Caenogastropoda: Ampullariidae) inhabiting Japanese paddy fields
}

\author{
Kazuhiro Yoshida, ${ }^{1}$ Kazuo HoshiKawa, ${ }^{2}$ Takashi WAdA ${ }^{3}$ and Yoichi Yusa, ${ }^{4, *}$ \\ ${ }^{1}$ The United Graduate School of Agricultural Sciences, Tottori University; Tottori 680-8553, Japan \\ ${ }^{2}$ Faculty of Life and Environmental Science, Shimane University; Matsue, Shimane 690-8504, Japan \\ ${ }^{3}$ National Agricultural Research Center for Kyushu Okinawa Region; Koshi, Kumamoto 861-1192, Japan \\ ${ }^{4}$ Faculty of Science, Nara Women's University; Nara 630-8506, Japan
}

(Received 22 December 2008; Accepted 13 April 2009)

\begin{abstract}
The life cycle of the apple snail Pomacea canaliculata was monitored over 2- and 1-year periods in Nara (cold district) and Kumamoto (warm district), respectively. The life cycles were similar in both districts: most hatchlings appeared after August, and although some had grown to $\geq 20 \mathrm{~mm}$ by autumn, the majority of juveniles remained $<20 \mathrm{~mm}$. The survival rate over winter was very low $(<1 \%)$ in Nara, and moderately low $(9 \%)$ in Kumamoto. After winter, survivors grew rapidly with low mortality, reproduced actively in summer, and most died during the following winter. The survival rate during mid-term drying (drying of fields for about 2 weeks in summer) in Nara was high (ca. $90 \%$ ) in both years. In Nara, snail density after winter decreased to 1/43 of that in Kumamoto, but survivors in Nara grew larger and laid more eggs. Due to these effects, egg density in July, and also snail density in September, in Nara recovered to ca. $1 / 3$ of that in Kumamoto.
\end{abstract}

Key words: Alien species; population dynamics; life history plasticity; rice field; survival rate

\section{INTRODUCTION}

The apple snail, Pomacea canaliculata (Lamarck) (Caenogastropoda: Ampullariidae), is a freshwater snail indigenous to tropical, subtropical or temperate South America (Martin et al., 2001; Martin and Estebenet, 2002). This snail invaded many Asian countries, mainly in the 1980s (Halwart, 1994). It voraciously attacks rice seedlings, and various control methods, including chemical, biological and cultural, have therefore been studied (Shobu, 1996; Wada, 2000; Takahashi et al., 2002; Wada et al., 2004).

On the other hand, few studies have examined its basic ecology, including life cycle and population dynamics under natural conditions (Ozawa and Makino, 1989; Shobu, 1996; Wada, 2000; Martin and Estebenet, 2002). In particular, none have monitored the snail populations over a long period $(>1$ year) on a regular basis (at least once a month), which impedes the elucidation of detailed life cycle patterns and population dynamics in this highly flexible (Estebenet and Cazzaniga, 1992; Martin and Estebenet, 2002) as well as fast-growing (Tanaka et al., 1999) snail.

Most population studies have so far been conducted either in the original locality (Argentina: Martin and Estebenet, 2002) or in relatively warm districts in Japan (Shizuoka, Pacific coast of Honshu Island: Ozawa and Makino, 1989; Kyushu Island: Shobu, 1996; Wada, 2000). Information concerning $P$. canaliculata in cold districts is very scarce (Suzuki and Fukuda, 1988; Ito, 2002); thus, it is unknown whether the snail leads similar life cycles in paddy fields in cold districts. The distribution of the snail continues to expand in East Asia, including Japan, China, and Korea (Joshi and Sebastian, 2006), and hence studies on the population dynamics and key regulating factors in cold districts are especially important for the prediction and prevention of further expansion. One key factor in the population dynamics of this snail is den-

* To whom correspondence should be addressed at: E-mail: yusa@cc.nara-wu.ac.jp DOI: $10.1303 / \mathrm{aez} .2009 .465$ 
sity dependence in growth and reproduction (Tanaka et al., 1999). Wada et al. (2004) reported a rapid population recovery during summer in paddy fields where snail densities had been low in June. Snail populations in colder districts may show similar rapid recovery even they suffer high mortality during winter (see below). This prediction should be tested in a field study.

Concerning the life cycle, two periods may be stressful to $P$. canaliculata in Japanese paddy fields: cold temperatures in winter, and drying-out in summer. Although the snails bury themselves in the soil, they do not have a high tolerance to low temperatures (Ozawa and Makino, 1988; Shobu et al., 2001; Wada and Matsukura, 2007), suggesting that winter survival is likely to be low in cold districts. In fact, $P$. canaliculata cannot survive over winter in paddy fields in Ibaraki, mid-Honshu Island (Ito, 2002). The second possibly stressful period is when the paddy fields dry out for about $2 \mathrm{wk}$ in summer (hereafter referred to as mid-term drying). Although this snail has a relatively high tolerance to long-term drying (Yusa et al., 2006), no information is available concerning its survival rates during mid-term drying.

The present study aimed to clarify the life cycle of $P$. canaliculata in Japanese paddy fields in detail and to determine basic population parameters, including growth, egg production, and survival rate. Detailed observations were made over 2 years in a cold district (Nara), and over 1 year in a warmer district (Kumamoto). We studied many (13-28) fields in each locality to draw a general conclusion on the life cycle there. Variations among fields within each locality will be treated in a separate paper.

\section{MATERIALS AND METHODS}

Sampling methods. $P$. canaliculata populations in Japanese paddy fields were monitored in two districts: within a $1 \mathrm{~km}^{2}$ area in Kashiwagi, Nara City, Honshu Island $\left(34^{\circ} 40^{\prime} \mathrm{N}, 135^{\circ} 47^{\prime} \mathrm{E}\right)$ and within a $0.5 \mathrm{~km}^{2}$ area in Shimo-suzurikawa, Kumamoto City, Kyushu Island $\left(32^{\circ} 51^{\prime} \mathrm{N}, 130^{\circ} 41^{\prime} \mathrm{E}\right)$. In Nara, fields are usually flooded for transplanting rice seedlings in early June, mid-term drying occurs from mid-July to early August, and fields are drained for harvesting in mid-September. In $\mathrm{Ku}-$ mamoto, fields are usually flooded in late June, dried from early to mid-August, and drained in mid- to late September.

In Nara, sampling was conducted twice a month from early June 2005 to early June 2006 in 16 paddy fields, except for during the intercrop season and mid-term drying. From late June 2006 to early June 2007, we increased the number of surveyed fields to 28 , due to the low density of snails, and decreased the sampling frequency to once a month. In Kumamoto, sampling was conducted four times in 13 fields: in early July, late July, early September 2006, and late June 2007. In choosing sampling sites, paddy fields were avoided where many snails appeared to have been killed recently (with undecomposed flesh) during the transplanting season, because pesticide might have been sprayed there. Subsequently, no such instance of mass mortality was observed during the rice-growing season at our sampling sites, except for two fields in Kumamoto in June 2007. The data from these two fields were excluded from the analysis for 2007.

Five quadrats of $1 \times 1 \mathrm{~m}$ (at intervals of $1 \mathrm{~m}$ ) were set $1 \mathrm{~m}$ from the water inlet along the levee in each field, and all snails $\geq 5 \mathrm{~mm}$ in shell height were collected. When the density of snails was extremely high $\left(\geq 50\right.$ individuals $\left./ \mathrm{m}^{2}\right)$, sampling of small snails $5-10 \mathrm{~mm}$ was conducted using five sub-quadrats of $0.2 \times 0.5 \mathrm{~m}$, each placed adjacent to the large quadrats. On the other hand, when snail density was low $\left(<5\right.$ individuals $\left./ \mathrm{m}^{2}\right)$, we tried to collect up to 30 snails found along the levee to obtain reliable size frequency distribution.

The shell height of each snail collected was measured to the nearest $0.1 \mathrm{~mm}$ using calipers, in order to monitor snail growth. Shell height was defined as the maximum length of the shell along a line from the apex to the center of the umbilicus (Fig. 1). After winter, snails had an overwintering inter-growth line on their shells as well as the opercula (Suzuki et al., 2000). Shell height in the overwintering period was estimated by measuring the height along the inter-growth line (Fig. 1). All snails $\geq 25 \mathrm{~mm}$ in shell height were sexed using the shapes of the shell and the operculum (Tanaka et al., 1999), to calculate egg production per female. All snails were released into the original fields after measurement.

In order to estimate egg density, the maximum length of each egg mass found in the $1 \times 1 \mathrm{~m}$ quadrats was measured to the nearest $0.1 \mathrm{~mm}$. The 


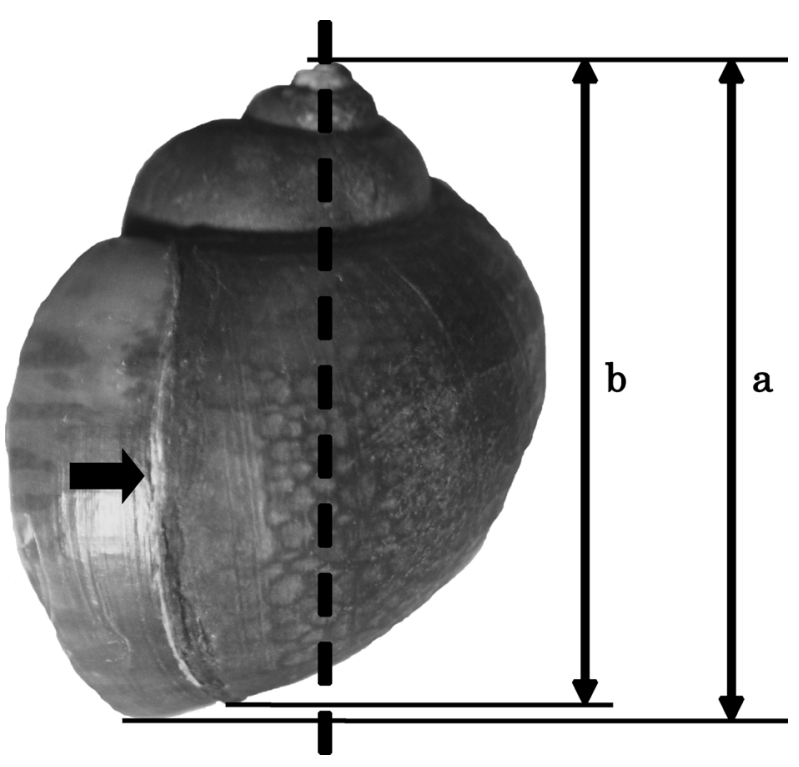

Fig. 1. The maximum shell height (a) and estimated shell height at overwintering using the inter-growth line (b) of $P$. canaliculata. Arrow indicates the overwintering inter-growth line and broken line shows the axis from the apex to the center of the umbilicus.

number of eggs in an egg mass was estimated using a regression equation provided by Dr. T. Watanabe (personal communication): $E N=$ 166.4EL-404.5, where $E N$ is the estimated egg number and $E L$ is the maximum length $(\mathrm{mm})$ of the egg mass, transformed to a natural logarithm.

Data and statistical analysis. Snail densities were calculated using data from quadrat samples. Data for $\geq 10 \mathrm{~mm}$ snails were always based on large quadrats, whereas data for smaller snails were based on smaller quadrats whenever available. The snails were classified into 5-mm interval size classes. The number of snails in each size class was calculated as the snail density multiplied by the proportion of snails in the class (based on all samples collected in both quadrats and surveys). All egg data were calculated based on $1 \times 1 \mathrm{~m}$ quadrat samples.

The overwintering survival rate for each field was estimated by dividing the density in the first sampling of the year by that in the last autumn sampling of the previous year. Likewise, the survival rate during mid-term drying was calculated based on the densities before and after mid-term drying in Nara in 2005 and 2006. Data for the Kumamoto population were not available due to the lack of sampling just after mid-term drying. To avoid random fluctuations due to extremely low snail densities in some paddy fields, we averaged the values from the two preceding samplings to provide the snail density before mid-term drying. After mid-term drying, many juveniles, born in summer, appeared and some might have reached the adult size (Fig. 2). Because the growth rates of juveniles varied from year to year, the upper limit of juvenile shell height just after mid-term drying was set at $20 \mathrm{~mm}$ in 2005, and $30 \mathrm{~mm}$ in 2006 in Nara to distinguish adults from juveniles. Attempts to distinguish snails in these generations by fitting normal curves in size distributions did not give reliable estimates, probably due to a large size variation in putative cohorts.

Ozawa and Makino (1988) proposed an index of cumulative low temperature (CLT) to explain the winter mortality of the snail. To calculate this index, we obtained hourly air temperature data for Nara and Kumamoto from the website of the Japan Meteorological Agency (The Meteorological Agency, 2007). CLT is given as the sum of differences between hourly air temperatures below $10^{\circ} \mathrm{C}$ and $10^{\circ} \mathrm{C}$ during October-March of the years when field samplings were conducted. The average air temperature in the same period was also calculated at each locality.

General linear mixed models were adopted to test the possible factors affecting survival rates, using JMP version 5.0.1 (SAS Institute, 2002). A model selection procedure was performed (Grafen and Hails, 2002), starting from a full model containing all independent variables (see below) and their interaction terms, with the identity of the paddy fields as a random factor using the REML method (SAS Institute, 2002). Non-significant interaction terms, and then non-significant independent variables, were successively removed by the order of larger $p$-values, until all variables in the model remained significant; however, the identity of paddy fields was always retained in the model as a random factor (Grafen and Hails, 2002). To analyze the factors affecting the survival rate, the initial full model incorporated year, locality, and shell height in September (for winter survival) or in July (for mid-term survival) as independent variables. To test the effects of temperature on winter survival, another model was used which incorporated CLT, instead of year and locality. All survival rates were inverse transformed after adding either 1 or 


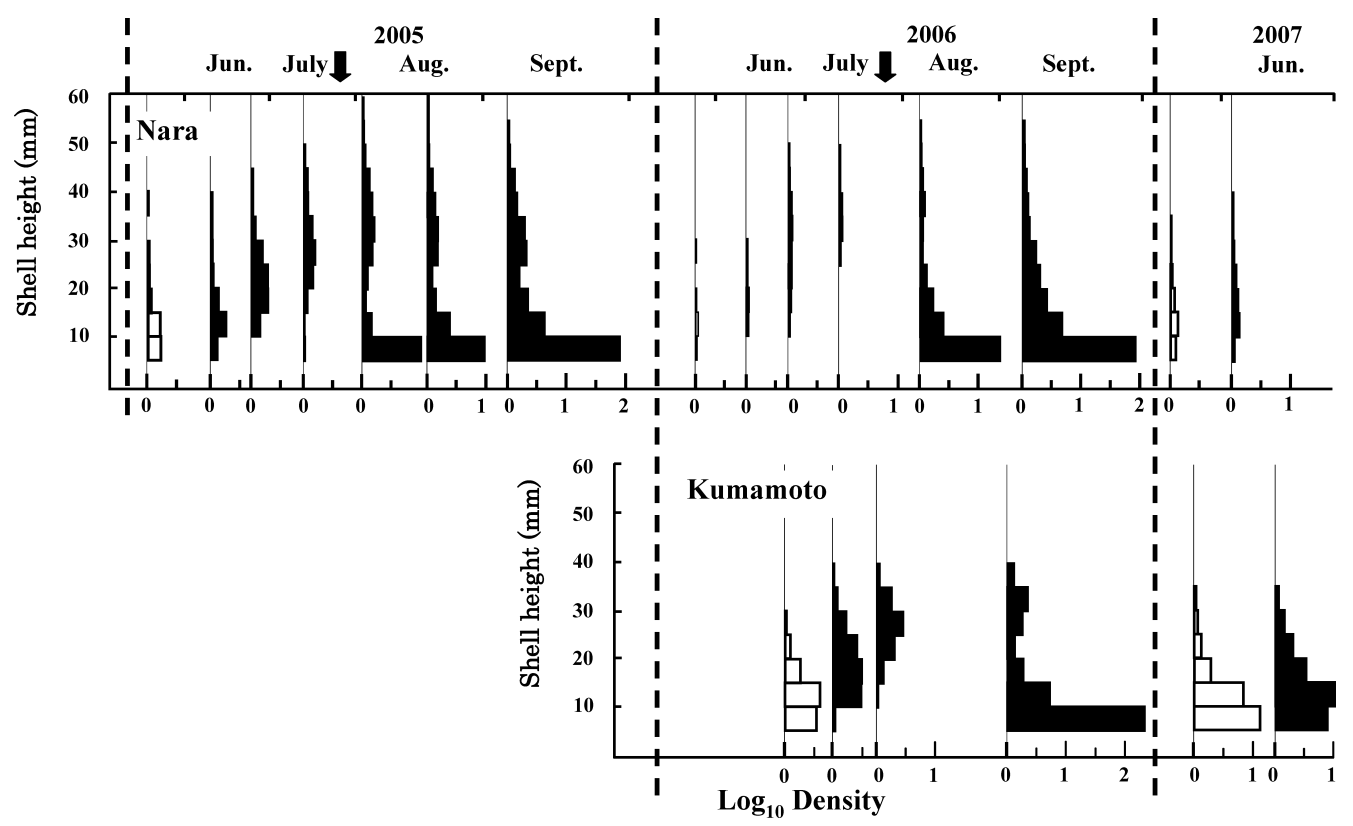

Fig. 2. Seasonal changes in shell height of P. canaliculata in Nara (above) and Kumamoto (below). Snail densities (no. of individuals $/ \mathrm{m}^{2}$ ) were transformed to the common logarithm after adding 1 to all data. Arrows indicate mid-term drying. Broken lines show the winter, and histograms just behind the broken lines show shell height distributions estimated using overwintering intergrowth lines (white bars; see Materials and Methods for details).

0.1 to meet the assumptions of normality and equal variance.

\section{RESULTS}

\section{Growth pattern}

Irrespective of year or locality, the shell heights of snails immediately after wintering were mainly within the range of $5-24.9 \mathrm{~mm}$, with a peak at $5-14.9 \mathrm{~mm}$ (Fig. 2). Among snails of 5-9.9 mm shell height, 7.5-9.9 mm individuals were 2.5-6.4 times more frequent than smaller individuals in all years and localities (mean density of 5-7.4 mm individuals was $0.0067-2.1 / \mathrm{m}^{2}$ depending on year and locality; density of 7.5-9.9 mm individuals was $0.033-9.9 / \mathrm{m}^{2}$ ). The snails showed rapid growth and reached almost the maximum size before mid-term drying in July. They then showed little further growth in shell height, and most had reached $\geq 25 \mathrm{~mm}$ by September. Several snails in Nara exceeded $40 \mathrm{~mm}$ in shell height, and some exceeded $50 \mathrm{~mm}$, whereas none reached $40 \mathrm{~mm}$ in $\mathrm{Ku}-$ mamoto. In both localities, few snails $\geq 30 \mathrm{~mm}$ survived over winter.

In Nara, newborn juvenile snails began to appear in August, and many had grown rapidly by September (Fig. 2). Although no data were available in
August, a similar trend appears to have existed in Kumamoto; however, the detailed growth patterns of juveniles differed between localities. In the Nara population, several juveniles attained $>20 \mathrm{~mm}$ in September, demonstrated by an increase in average density of $\geq 20 \mathrm{~mm}$ snails from July to September in both 2005 and 2006 (from 1.2 to $2.3 / \mathrm{m}^{2}$ in 2005; from 0.14 to $1.8 / \mathrm{m}^{2}$ in 2006). In the Kumamoto population, however, almost all juveniles appeared to have maintained $<20 \mathrm{~mm}$ in shell height, as the average density of $\geq 20 \mathrm{~mm}$ snails decreased from July to September (from 2.7 to $1.3 / \mathrm{m}^{2}$ in 2006).

\section{Density changes and survival rates}

Snail density after overwintering varied between localities and years (Fig. 3). The density after winter of the Kumamoto population was higher than that of the Nara population (43-fold higher in 2006: $6.4 / \mathrm{m}^{2}$ in early July in Kumamoto vs. $0.15 / \mathrm{m}^{2}$ in early June in Nara; 25 -fold higher in 2007: $19 / \mathrm{m}^{2}$ in late June in Kumamoto vs. $0.76 / \mathrm{m}^{2}$ in early June in Nara). Although less extremely, densities also differed between years (Fig. 3), by almost 10 -fold in Nara $\left(1.4 / \mathrm{m}^{2}\right.$ in early June 2005 ; $0.15 / \mathrm{m}^{2}$ in $2006 ; 0.76 / \mathrm{m}^{2}$ in 2007$)$ and almost 3 fold in Kumamoto $\left(6.4 / \mathrm{m}^{2}\right.$ in $2006 ; 19 / \mathrm{m}^{2}$ in 2007). 


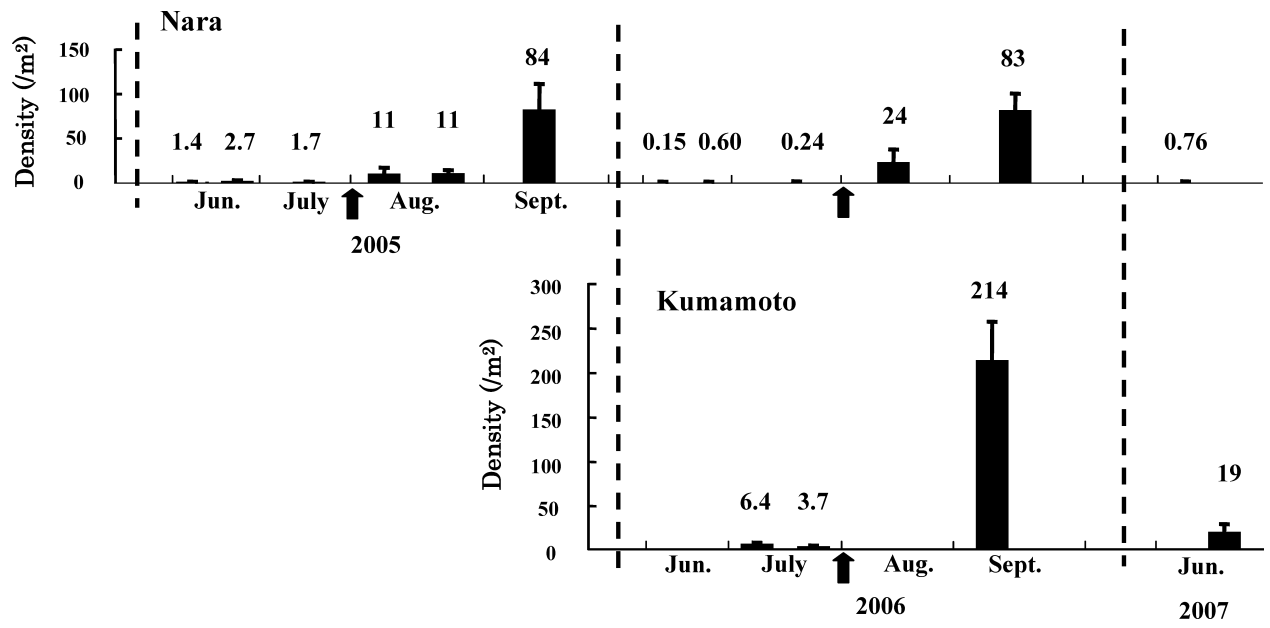

Fig. 3. Seasonal changes in density of $P$. canaliculata in Nara (above) and Kumamoto (below). Given as averages \pm SEs of the paddy fields surveyed. Numerals indicate average values, arrows indicate mid-term drying, and broken lines show the winter.

Table 1. Synopsis of overwintering P. canaliculata populations in Nara and Kumamoto, including size and density before and after winter, survival rate and temperature conditions

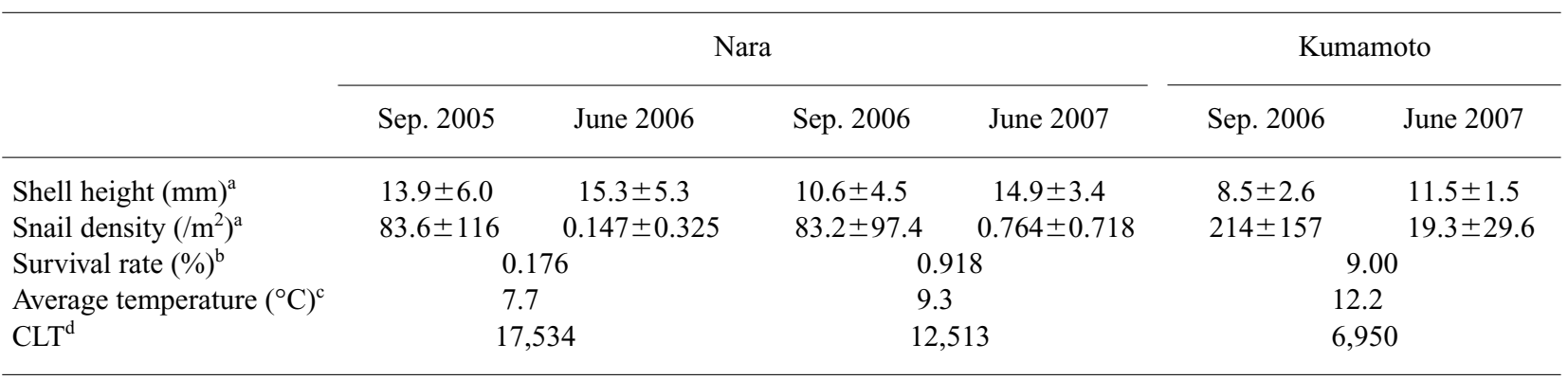

${ }^{\text {a }}$ Average \pm SE of paddy fields.

${ }^{\mathrm{b}}$ Average density in June/average density in September.

${ }^{\mathrm{c}}$ Average winter air temperature (October-March) in the study years.

${ }^{\mathrm{d}}$ Cumulative low temperature index (sum of difference between the hourly air temperature below $10^{\circ} \mathrm{C}$ and $10^{\circ} \mathrm{C}$ in $\mathrm{October}-$ March in the study years).

The overwintering survival rate was relatively high in the 2006-2007 winter in Kumamoto (9.0\%), lower in the 2006-2007 winter in Nara $(0.92 \%)$, and lowest in the 2005-2006 winter in Nara $(0.18 \%)$ (Table 1$)$. This order corresponds to the order of the average winter air temperatures and is the opposite of the order of CLT values (Table 1). In the minimum model in the model selection procedure, winter survival was affected by year, locality, shell height in September and the interaction term between year $\times$ shell height (Table 2A). When the CLT index was incorporated instead of year and locality as an independent variable (Table 2B), survival was significantly affected by CLT, shell height and their interaction term.

The density of snails that survived winter did not appear to change markedly until newborns were recruited, suggesting a high survival rate in paddy fields during the crop season (Fig. 3). The density of newborns continued to increase from August, and was $>80 / \mathrm{m}^{2}$ before draining in September (Fig. 3). In September, the density of total snails, the majority of which were juveniles, in $\mathrm{Ku}$ mamoto $\left(214 / \mathrm{m}^{2}\right.$ in 2006) was 2.6-fold higher than that in Nara $\left(84 / \mathrm{m}^{2}\right.$ in $2005 ; 83 / \mathrm{m}^{2}$ in 2006$)$, but the difference was much less than in June.

The survival rate of adult snails during mid-term drying in Nara was very high $(90 \%$ in $2005 ; 89 \%$ in 2006), despite their exposure to high temperature and aridity during the period. The difference between years was small, but significant (Table 3). Neither shell height before mid-term drying nor the 
Table 2. Minimum model concerning the factors affecting the overwinter survival rate in Nara and Kumamoto populations of $P$. canaliculata

A. Years and localities

\begin{tabular}{lccccc}
\hline \multicolumn{1}{c}{ Factor } & Degree of freedom & Sum of squares & Mean square & $F$ value & $p$ value \\
\hline Year & 1 & 10.8 & 10.8 & 11.5 & 0.006 \\
Locality & 1 & 11.1 & 11.1 & 11.9 & 0.001 \\
Shell height & 1 & 5.62 & 5.62 & 43.9 & 0.032 \\
Year $\times$ shell height & 1 & 41.0 & 41.0 & & \\
Paddy field (within locality) & 36 & 142 & 0.96 & \\
\hline Error term & 11 & 10.3 & 0.933 & \\
\hline
\end{tabular}

B. Cumulative low temperature

\begin{tabular}{lccccc}
\hline \multicolumn{1}{c}{ Factor } & Degree of freedom & Sum of squares & Mean square & $F$ value & $p$ value \\
\hline CLT & 1 & 69.0 & 69.0 & 35.6 & 17.4 \\
Shell height & 1 & 33.7 & 33.7 & 18.6 & 0.001 \\
CLT $\times$ shell height & 1 & 36.0 & 36.0 & & 0.001 \\
Paddy field $^{\text {a }}$ & 37 & 100 & 2.71 & & \\
\hline Error term & 11 & 21.3 & 1.94 & \\
\hline
\end{tabular}

${ }^{\mathrm{a}}$ Treated as a random factor.

Table 3. Minimum model concerning the factors affecting the survival rate during mid-term drying in Nara population of $P$. canaliculata

\begin{tabular}{lcccc}
\hline \multicolumn{1}{c}{ Factor } & Degree of freedom & Sum of squares & Mean square & $F$ value \\
\hline Year & 1 & 0.326 & 0.326 & 0.49 \\
Paddy field $^{\mathrm{a}}$ & 26 & 1.89 & 0.0727 & 0.031 \\
\hline Error term & 9 & 0.452 & 0.0502 & \\
\hline
\end{tabular}

${ }^{\text {a }}$ Treated as a random factor.

interaction term between year $\times$ shell height was selected in the minimum model in the model selection procedure.

\section{Oviposition activity}

The number of egg masses was small in June, and peaked in July before mid-term drying, and then decreased again (Fig. 4). The average density of egg masses in July was higher in Kumamoto $\left(2.11 / \mathrm{m}^{2}\right.$ in 2006) than in Nara $\left(0.96 / \mathrm{m}^{2}\right.$ in 2005 ; $0.46 / \mathrm{m}^{2}$ in 2006).

The maximum length of egg masses showed a less clear seasonal trend, but became largest in July or August and then slightly decreased (Fig. 4). The egg mass length in the Kumamoto population appeared to be smaller than in the Nara population.
The density of eggs, estimated from the number and size of egg masses, tended to show similar seasonal changes between different years or localities (Fig. 4). It increased from June, peaked before mid-term drying in July, and decreased again towards September. The average egg density in July was higher in Kumamoto $\left(193 / \mathrm{m}^{2}\right.$ in 2006) than in Nara $\left(132 / \mathrm{m}^{2}\right.$ in $2005 ; 73 / \mathrm{m}^{2}$ in 2006). The difference was nearly 2.6 -fold between localities in the same year, and 1.8-fold between different years in the Nara population.

To investigate the factors affecting snail densities in September between different years or localities, egg production per female and juvenile survival were estimated. The average number of eggs per female in July, when egg production peaked, 


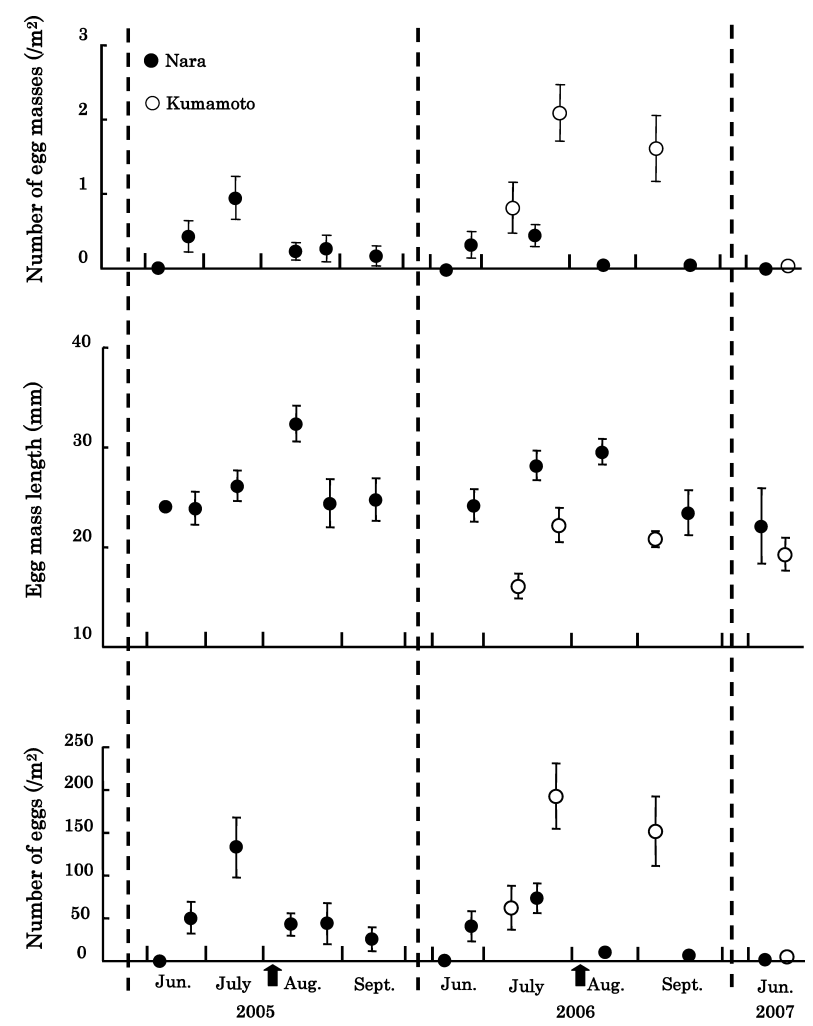

Fig. 4. Seasonal changes in oviposition activities of $P$. canaliculata in Nara (closed circles) and Kumamoto (open circles). Number of egg masses (above), maximum length of respective egg mass (middle), and number of eggs estimated (below) are shown. Given as averages \pm SEs of the paddy fields. Arrows indicate mid-term drying, and broken lines show the winter.

was largest (437 eggs/female) in Nara in 2006, second largest (152) in Nara in 2005, and smallest (115) in Kumamoto in 2006. This was the opposite of the order of snail density after winter, and there was a 3.8-fold difference between localities in 2006. As an index of survival from eggs to juveniles, the number of snails in September (the majority being newborn juveniles) was divided by the egg number in July. The index did not differ much between years (0.64 in 2005 and 1.1 in 2006 in Nara) or localities (1.1 in Kumamoto in 2006).

\section{DISCUSSION}

\section{Life cycle}

This study clarified the life cycle of $P$. canaliculata in a cold district (Nara) in detail and, with less accuracy, that in a warm district (Kumamoto). The basic life cycles were similar in both districts and can be summarized as follows: small juveniles
( $\geq 5 \mathrm{~mm}$ shell height) appeared after mid-term drying in August, and some grew to $\geq 20 \mathrm{~mm}$ by September, although the majority remained $<20 \mathrm{~mm}$. P. canaliculata reach sexual maturity at ca. $25 \mathrm{~mm}$ (Estoy et al., 2002), but it was not clear from the present study whether these individuals reproduce within the same year. Most snails die during the winter, but a small proportion of 5-25 mm snails (the majority being $5-15 \mathrm{~mm}$ ) survives over winter. The survivors grow rapidly and begin to reproduce before mid-term drying, after which they undergo little further growth. These general patterns are common in other study populations in warm districts (Shizuoka: Ozawa and Makino, 1988; Kyushu Island: Tanaka et al., 1999; Suzuki et al., 2000; Watanabe et al., 2000; Shobu et al., 2001); therefore, snails in cold districts have similar life cycles to those in warmer districts, irrespective of low survival during winter.

This study also clarified that few large individuals $\geq 30 \mathrm{~mm}$ survive over winter, irrespective of year and locality. This result supports the previous suggestion that few snails survive two summer seasons in Japanese paddy fields (Wada, 2000). P. canaliculata can adapt its life history according to the ambient temperature. Estebenet and Cazzaniga (1992) reported that $P$. canaliculata in Argentina lived for less than 1 year and reproduced for one season (semelparous) when kept at a constant temperature of $25^{\circ} \mathrm{C}$, but they lived for up to 4 years, and reproduced over 2-3 years (iteroparous) when kept at variable room temperature. Despite variable temperature conditions, $P$. canaliculata in Japanese paddy fields appears to be semelparous; however, this cannot be regarded as evidence of rapid life history evolution after introduction into Japan, as snails may also be semelparous in some field populations in Argentina, considering inter-population variations in life history traits (Martin and Estebenet, 2002).

\section{Survival during mid-term drying and over win- ter}

The survival rate of $P$. canaliculata during midterm drying was generally high (ca. 90\%) in Nara. This was rather unexpected, because this snail is susceptible to high temperatures (Miyahara et al., 1986a; Kaneshima et al., 1987), although it is relatively resistant to aridity (Yusa et al., 2006). We were unable to determine the survival rate of $P$. 
canaliculata during mid-term drying in $\mathrm{Ku}-$ mamoto, but it might be slightly lower because the average air temperature in August is higher than in Nara $\left(27.7^{\circ} \mathrm{C}\right.$ in Kumamoto vs. $26.6^{\circ} \mathrm{C}$ in Nara during 1971-2000; The Meteorological Agency, 2007).

The survival rate of snails over winter was much lower in Nara $(0.18-0.92 \%$ depending on year) than in Kumamoto $(9.0 \%)$. The survival rate in Nara also appears to be lower than in other studies conducted in warm districts $(8-15 \%$ in Kumamoto, Kyushu: Watanabe et al., 2000; Wada and Matsukura, 2007; 18-67\% in Saga, Kyushu: Shobu et al., 2001; 60\% in Shizuoka: Ozawa and Makino, 1988), although direct comparison is difficult due to differences in field conditions, methods of investigation, and snail size (Shobu et al., 2001). In this study, the results of a general linear mixed model showed that cumulative low temperature had a significant effect on snail survival over winter, as well as in previous studies (Ozawa and Makino, 1988; Shobu et al., 2001); therefore, the main factor affecting winter survival appears to be a climatic factor represented by the CLT index, and is likely to be low temperature itself. However, differences in other factors, such as precipitation, soil conditions and culturing practice, should also be taken into account. In addition, estimates of survival rates in our study might have been obscured by factors such as the migration of snails after irrigation, since our surveys were sometimes conducted several days after irrigation. Further study is needed to obtain accurate estimates of survival rates and the environmental factors affecting them.

Snail size also affected winter survival, and most survivors were snails of $5-15 \mathrm{~mm}$ shell height. Among snails of $5-10 \mathrm{~mm}, 7.5-10 \mathrm{~mm}$ individuals were more frequent than smaller individuals. These results are in general agreement with previous reports where $10-20 \mathrm{~mm}$ snails survived best over winter (Oya et al., 1987; Watanabe et al., 2000; Wada and Matsukura, 2007). Snails of this size are also known to be resistant to aridity (Yusa et al., 2006). Smaller individuals are generally more susceptible to harsh environments, probably because they have a relatively large surface area: volume ratio, while larger individuals have lower survival rates either because they are exhausted after reproduction (post-reproductive die-off: Darby et al., 2003) or because they are more likely to be killed by tillage (Wada et al., 2004).

\section{Population dynamics in the cold district}

The average snail density in June in Nara was only $1 / 43$ of that in Kumamoto, but the density in September had recovered to $1 / 3$ of that in $\mathrm{Ku}-$ mamoto. Likewise, the density in June varied by as much as a multiple of ten between years in Nara, whereas the density was similar in September. Thus, mechanisms exist that allow the recovery of populations in cold districts such as Nara.

Since juveniles in September hatched from eggs laid in summer, the number of eggs in summer is expected to affect the density of juveniles in September. In fact, the variation in egg numbers between different localities or years showed similar trends to those in snail densities: the number of eggs $/ \mathrm{m}^{2}$ in July in Nara was about $1 / 3$ of that in Kumamoto, and it differed $<2$-fold between years in Nara; therefore, the key mechanism for population recovery appeared to be oviposition activity. In Nara, snails grew larger than in Kumamoto, probably due to density-dependent effects (Tanaka et al., 1999). Egg masses in Nara tended to be larger, as large snails tend to lay larger egg masses (Miyahara et al., 1986b). Thus, low winter survival in the Nara population was largely compensated for by higher fecundity, and the same was true for population recovery in different years in Nara. In fact, the number of eggs per female was highest in 2006 in Nara, followed by in 2005 in Nara and lowest in 2006 in Kumamoto, showing an inverse order of the density of snails after winter. On the other hand, survival from egg to juveniles did not differ much between years or localities. This mechanism of density-dependent growth and reproduction appears to allow the snails to maintain similar life cycles in different localities, despite much different overwintering survival rates and initial densities at the beginning of the season. The success of this snail as an invasive species, now distributed over a wide area in tropical, subtropical and temperate America and Asia (Joshi and Sebastian, 2006), may depend on this high reproductive potential and flexibility.

In Nara, snail density after winter was $0.15 / \mathrm{m}^{2}$ in 2006, when winter temperatures were lowest during our study. This density was almost the same as that after crop rotation to soybean for 1 year in Kyushu $\left(0.14 / \mathrm{m}^{2}\right.$ : Wada et al., 2004), and lower 
than the minimum density requiring snail control under direct sowing practice $\left(0.25 / \mathrm{m}^{2}\right.$ : Shobu and Mikuriya, 2003). Even in other years, snail densities after winter were $0.76-1.4 / \mathrm{m}^{2}$ in Nara, which were lower than the densities in Kyushu $\left(6.4-19 / \mathrm{m}^{2}\right.$ : present study; $1.7-3.8 / \mathrm{m}^{2}$ : Watanabe et al., 2000; Wada et al., 2004). The average densities in Nara were lower than the minimum density requiring snail control for transplanting $\left(1.5 / \mathrm{m}^{2}\right.$ : Shobu and Mikuriya, 2003), suggesting that no control practice appears to be necessary in most paddy fields in Nara; however, careful monitoring is required because snail densities are higher in some fields, and some damage occurs (Yoshida, personal observations). Monitoring is also important because snail densities after winter in cold districts such as Nara may increase in the future, due to adaptation to the colder climate by snails, and to global warming.

\section{ACKNOWLEDGEMENTS}

We are grateful to Dr. Keiji Wada and members of the Laboratory of Population and Community Ecology at Nara Women's University for discussion, and to anonymous reviewers for constructive comments. We also thank Noriomi Fujimori and farmers for help in the fields, and Dr. Tomonari Watanabe for providing data on egg mass length and egg number.

\section{REFERENCES}

Darby, P. C., P. L. Valentine-Darby and H. F. Percival (2003) Dry season survival in a Florida apple snail (Pomacea paludosa Say) population. Malacologia 45: 179-184.

Estebenet, A. L. and N. J. Cazzaniga (1992) Growth and demography of Pomacea canaliculata (Gastropoda: Ampullariidae) under laboratory conditions. Malac. Rev. 25: $1-12$

Estoy, G. F., Jr., Y. Yusa, T. Wada, H. Sakurai and K. Tsuchida (2002) Size and age at first copulation and spawning of the apple snail, Pomacea canaliculata (Gastropoda: Ampullariidae). Appl. Entomol. Zool. 37: 199-205.

Grafen, A. and R. Hails (2002) Modern Statistics for the Life Sciences. Oxford University Press, Oxford. 351 pp.

Halwart, M. (1994) The golden apple snail Pomacea canaliculata in Asian rice farming systems: present impact and future threat. Int. J. Pest Manag. 40: 199-206.

Ito, K. (2002) Environmental factors influencing overwintering success of the golden apple snail, Pomacea canaliculata (Gastropoda: Ampullariidae), in the northernmost population of Japan. Appl. Entomol. Zool. 37: 655-661.

Joshi, R. C. and L. C. Sebastian (2006) Global Advances in Ecology and Management of Golden Apple Snails. Philippine Rice Research Institute, Nueva Ecija, Philippines. $588 \mathrm{pp}$.

Kaneshima, M., S. Yamauchi and T. Kurozumi (1987) Effect of rearing temperature and density upon the growth of apple snail, Pomacea canaliculata (Lamarck). Proc. Assoc. Pl. Prot. Kyushu 33: 110-112 (in Japanese).

Martin, P. R. and A. L. Estebenet (2002) Interpopulation variation in life-history traits of Pomacea canaliculata (Gastropoda: Ampullariidae) in southwestern Buenos Aires Province, Argentina. Malacologia 44: 153-163.

Martin, P. R., A. L. Estebenet and N. J. Cazzaniga (2001) Factors affecting the distribution of Pomacea canaliculata (Gastropoda: Ampullariidae) along its southernmost natural limit. Malacologia 43: 13-23.

Miyahara, Y., Y. Hirai and S. Oya (1986a) Occurrence of Ampullarius insularus D’Orbigny injuring lowland crops. Plant Prot. 40: 31-35 (in Japanese).

Miyahara, Y., Y. Hirai and S. Oya (1986b) Oviposition and hatching rate of Ampullarius insularus D'Orbigny in Kyushu. Proc. Assoc. Pl. Prot. Kyushu 32: 96-100 (in Japanese).

Oya, S., Y. Hirai and Y. Miyahara (1987) Overwintering of the apple snail, Pomacea canaliculata Lamarck, in north Kyushu. Jpn. J. Appl. Entomol. Zool. 31: 206-212 (in Japanese with English summary).

Ozawa, A. and T. Makino (1988) Overwintering of the apple snail, Pomacea canaliculata (Lamarck), in Shizuoka prefecture. Bull. Shizuoka Agric. Exp. Stn. 33: 65-77 (in Japanese).

Ozawa, A. and T. Makino (1989) Biology of the apple snail, Pomacea canaliculata (Lamarck), and its control. Plant Prot. 43: 502-505 (in Japanese).

SAS Institute (2002) JMP: Statistics and Graph Function Guide, version 5.0.1. SAS Institute, Tokyo. 740 pp. (in Japanese).

Shobu, S. (1996) Biology of apple snail, Pomacea canaliculata (Lamarck), and its control. Plant Prot. 50: 211-217 (in Japanese).

Shobu, S. and H. Mikuriya (2003) Control threshold of the apple snail, Pomacea canaliculata (Lamarck) (Gastropoda: Ampullariidae) in water seeded rice and transplanted young rice seedlings. Kyushu Agric. Res. 65: 95 (in Japanese).

Shobu, S., H. Mikuriya, J. Yamaguchi, M. Matsuzaki, S. Zen and T. Wada (2001) Estimating the overwintering mortality of the apple snail, Pomacea canaliculata (Lamarck) (Gastropoda: Ampullariidae) in a paddy field of Southern Japan using temperature data. Jpn. J. Appl. Entomol. Zool. 45: 203-207 (in Japanese with English summary).

Suzuki, M. and T. Fukuda (1988) Seasonal occurrence of the apple snail, Pomacea canaliculata (Lamarck). Proc. Kanto-Tosan Pl. Prot. Soc. 35: 219-220 (in Japanese).

Suzuki, Y., M. Matsumura, K. Arimura and S. Urano (2000) Growth of overwintered generation of the golden apple snail, Pomacea canaliculata (Gastropoda: Ampullariidae) in a direct-seeded paddy field. Kyushu Agric. Res. 62: 90 (in Japanese).

Takahashi, K., M. Seki and H. Nishida (2002) Research for control of apple snail by rotary cultivator. Nougyou Kikai Gakkaishi 64(6): 76-81 (in Japanese with English summary).

Tanaka, K., T. Watanabe, H. Higuchi, K. Miyamoto, Y. Yusa, 
T. Kiyonaga, H. Kiyota, Y. Suzuki and T. Wada (1999) Density-dependent growth and reproduction of the apple snail, Pomacea canaliculata: a density manipulation experiment in a paddy field. Res. Popul. Ecol. 41: 253262.

The Meteorological Agency (2007) Japan Meteorological Agency. http://www.jma.go.jp/jma/index.html

Wada, T. (2000) Pomacea canaliculata. Nougyou-oyobiEngei 75(1): 215-220 (in Japanese).

Wada, T. and K. Matsukura (2007) Seasonal changes in cold hardiness of the invasive freshwater apple snail, Pomacea canaliculata (Lamarck) (Gastropoda: Ampullariidae). Malacologia 49: 383-392.

Wada, T., K. Ichinose, Y. Yusa and N. Sugiura (2004) Decrease in density of the apple snail Pomacea canaliculata
(Lamarck) (Gastropoda: Ampullariidae) in paddy fields after crop rotation with soybean, and its population growth during the crop season. Appl. Entomol. Zool. 39: 367-372.

Watanabe, T., K. Tanaka, H. Higuchi, K. Miyamoto, T. Kiyonaga, H. Kiyota, Y. Suzuki and T. Wada (2000) Emergence of the apple snail, Pomacea canaliculata (Gastropoda: Ampullariidae), after irrigation in a paddy. Appl. Entomol. Zool. 35: 75-79.

Yusa, Y., T. Wada and S. Takahashi (2006) Effects of dormant duration, body size, self-burial and water condition on the long-term survival of the apple snail, Pomacea canaliculata (Gastropoda: Ampullariidae). Appl. Entomol. Zool. 41: 627-632. 